\title{
Painful, pediatric sacral aneurysmal bone cyst treated by curettage and fresh frozen allograft
}

\author{
Küretaj ve taze dondurulmuş allogreft ile tedavi edilmiş, ağrılı, \\ pediatrik bir sakral anevrizmal kemik kisti
}

\author{
Murat Aydın, MD.,' Güray Toğral, MD.,, Fevzi Kekeç, MD.,, Murat Arıkan,MD.,, Şafak Güngör, MD. ${ }^{2}$ \\ 1'Department of Orthopedics and Traumatology, Afyonkarahisar Şuhut State Hospital, Afyonkarahisar, Turkey \\ ${ }^{2}$ Department of Orthopedics and Traumatology, Dr. Abdurrahman Yurtaslan Oncology Training and Research Hospital, Ankara, Turkey
}

\begin{abstract}
In this article, we report a rarely localized sacral aneurysmal bone cyst (ABC) successfully treated by curettage and bone grafting with fresh frozen fibular allograft (FFA) in a 14-year-old girl patient. The cyst was at S1-2 level and treated with aggressive curettage and bone grafting with two FFAs. All complaints of the patient resolved at the $24^{\text {th }}$ month of treatment and bony union of the cystic cavity was observed radiologically. Curettage and FFA may be safely used for filling the cavity in the treatment of sacral $\mathrm{ABC}$ in pediatric age to provide a structural and biological reinforcement.
\end{abstract}

Keywords: Aneurysmal; bone cysts; curettage; sacrum.

Aneurysmal bone cysts (ABCs) are expansile, lytic lesions of bone, which histologically show thin-walled, blood-filled cavities lacking normal endothelium and elastic lamina. In whole sacral tumors; giant cell tumor is the most common and constitutes nearly half of benign sacral tumors. ${ }^{[1]}$ Aneurysmal bone cysts are destructive cystic lesions of the bone more commonly seen in young adults in their twenties and they are rare and only account for less than $4 \%$ of the reported cases. ${ }^{[2]}$ Since the age of the patient and location along with radiographic characteristics of the lesions can resemble telangiectatic osteosarcoma or other malignant cystic lesions, histopathologic confirmation before operating is necessary. Aneurysmal bone cysts typically occur in $30-40 \%$ of different underlying
$\ddot{O} Z$

$\mathrm{Bu}$ yazıda, 14 yaşında bir kız hastada küretaj ve taze dondurulmuş fibula allogrefti (TDFA) ile kemik greftlemesi yoluyla başarılı bir şekilde tedavi edilen nadir yerleşimli bir sakral anevrizmal kemik kisti (AKK) sunuldu. Kist S1-2 seviyesindeydi ve agresif küretaj ve iki adet TDFA ile kemik greftlemesi yoluyla tedavi edildi. Tedavinin 24. ayında hastanın tüm yakınmaları düzeldi ve radyolojik olarak kistik kavitenin kemik kaynaması görüldü. Çocukluk çağında sakral AKK tedavisinde küretaj ve TDFA yapısal ve biyolojik iyileşme sağlamak amacıyla kaviteyi doldurmak için güvenle kullanılabilir.

Anahtar sözcükler: Anevrizmal; kemik kistleri; küretaj; sakrum.

bone tumors, mostly malignant entities such as e.g. osteosarcomas (showing the same typical radiographic signs in magnetic resonance imaging (MRI) and computed tomography (CT) scans with fluid levels and sedimentation signs etc.), preoperative incisional or a CT guided percutaneous biopsy, which is less reliable, is mandatory. Intralesional curettage for secondary $\mathrm{ABC}$ accompanying a sarcoma is the wrong therapy with dissemination of tumor cells and a higher rate of local recurrence. As a result, a correctly performed biopsy has outstanding prognostic importance. The sacrum is an unusual localization for $A B C s$ and even when they occur, they are asymptomatic in the initial stages of the disease; their expansile nature can cause pain through pathological fracture or by

- Received: November 06, 2015 Accepted: November 24, 2015

- Correspondence: Murat Aydın, MD. Afyonkarahisar Șuhut Devlet Hastanesi Ortopedi ve Travmatoloji Anabilim Dalı, 03800 Şuhut, Afyonkarahisar, Turkey. Tel: +90 532 - 4528559 Fax: +90 272 - 7184261 e-mail: opr.murataydin@gmail.com 


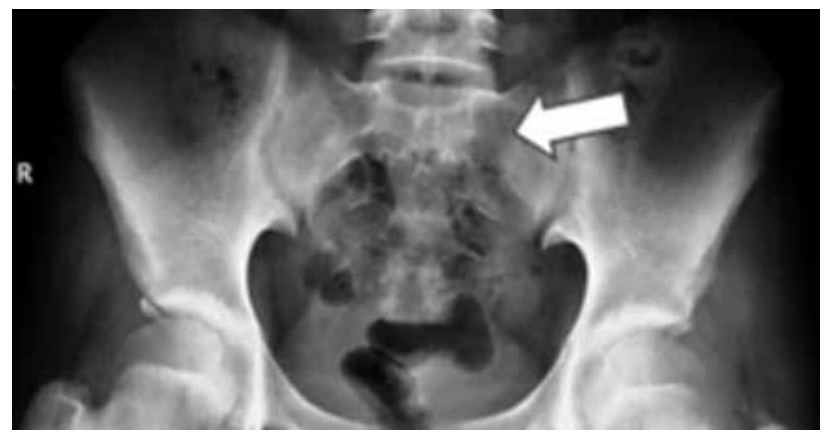

Figure 1. Preoperative anteroposterior pelvic X-ray, arrow showing the septated lytic lesion located at left S1-2 level near sacroiliac joint.

neurological compromise. ${ }^{[3]}$ A differential diagnosis between benign bone tumors should be done before performing treatment. The accepted treatment for aneurysmal bone cysts in the sacrum is aggressive curettage or en bloc resection followed by local adjuvant treatments and bone grafting. In this case, we preferred to fill the curetted cavity in the sacrum with tricalcium sulfate grafts and fresh frozen fibular allograft in order to enhance the stability of the curetted cavity. Preoperative selective arterial embolization (SAE) is the current updated treatment modality prior to surgical resection in order to avoid a possible major intraoperative hemorrhage. ${ }^{[3]}$

\section{CASE REPORT}

A 14-year-old girl was referred to our clinic 24 months ago with sacral and leg pain. Over the course of three months, she described worsening pain in the sacral region, radiating into the back which prevented her from sitting for prolonged periods or from walking. Her pain was so serious that she could not stand in an upright position or walk for any distance. A neurological examination revealed no abnormalities but because of the severity of pain she was bedridden. Her preoperative VAS score was 9 for back pain and 2 for leg pain. Laboratory examinations were within normal ranges except for low hemoglobin $(\mathrm{Hb})$ levels of $9.8 \mathrm{mg} / \mathrm{dL}$. X-rays showed an expansile, lytic and septated lesion at S1-2 levels on the left side (Figure 1). Pelvic CT revealed an expansile and destructive bone lesion at S1-S2 level, extending to the left sacroiliac joint (Figure 2a). Sagittal and axial lumbosacral MRI sequences showed a cystic, lobulated lesion, containing fluid levels in the left sacrum at S1-S2 level (Figure 3a, b). Involvement of the sacral spinal canal and compression of S2 nerve root was noted in these images, which could explain the severe pain. Left sacroiliac invasion in the medial side of the joint was present. In light of these clinical and radiological circumstances, a possible diagnosis of a bone neoplasm like telangiectatic osteosarcoma or a benign cystic lesion was suspected. A preoperative incisional biopsy was undertaken to rule out malignancy. A written informed consent was obtained from the family of patient. Diagnosis of $A B C$ was confirmed and an urgent treatment plan was decided upon because of the high level of pain. Pelvic angiography of the patient showed a hypervascular expansile lesion at the left side of the S1-2 region (Figure 2b). Considering that a hypervascular large $\mathrm{ABC}$ in this anatomical location carries a profuse bleeding risk, a preoperative SAE of the lesion was carried out in the interventional radiology unit one day before surgery. Two arterial branches feeding the tumor were partially embolized. Surgery was planned for the day after the remobilization,. As the patients' $\mathrm{Hb}$ levels were low, 5 units of packed erythrocytes were prepared. She was given general anesthesia and positioned in a prone position suitable for a posterior incision over the sacral wing. After dissecting the paravertebral muscles, the lesion was isolated at S1-2 level. After preparing the bony window, the cystic, septated lesion, intralesional subtotal resection of the
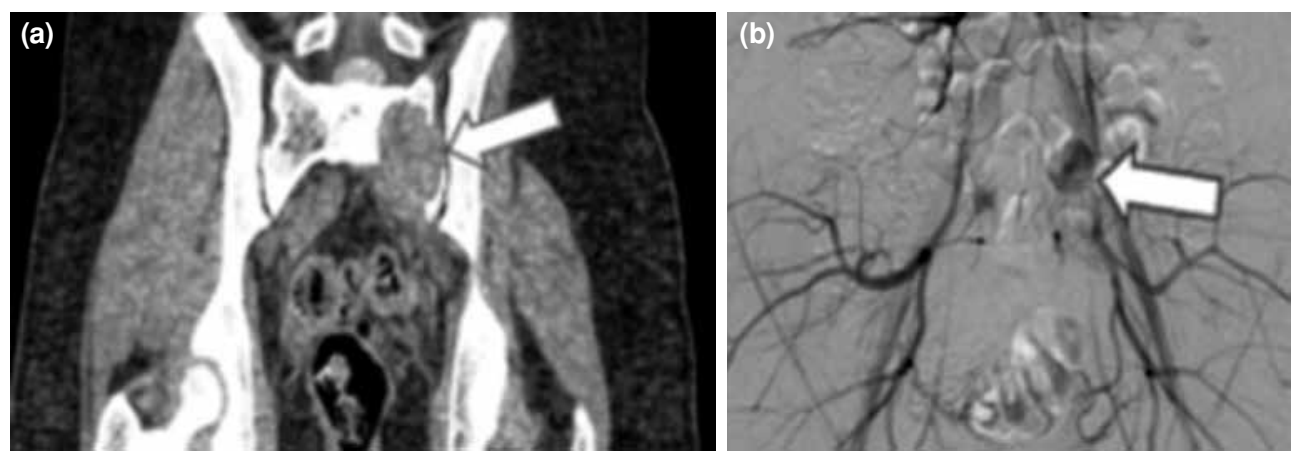

Figure 2. (a) Coronal computed tomography revealing an expansile and destructive bone lesion (arrow) at S1-2 level, extending to left sacroiliac joint. (b) Pelvic angiography of the patient showing a hypervascular expansile lesion at the left side of the S1-2 region (arrow). 

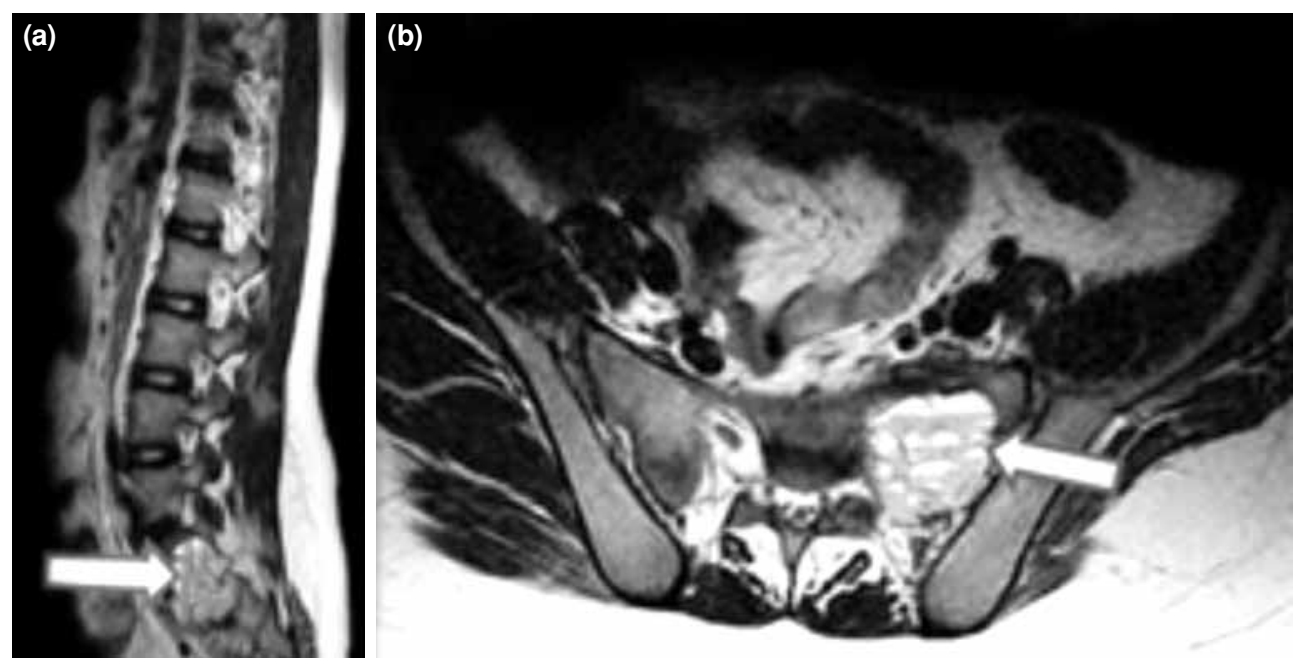

Figure 3. (a) Sagittal lumbosacral magnetic resonance imaging sequences showing a cystic, lobulated lesion, containing fluid levels in the left sacrum at S1-2 level. (b) Axial lumbosacral magnetic resonance imaging sequences showed a cystic, lobulated lesion, containing fluid levels in the left sacrum at S1-2 level (arrow).

tumor followed by homograft and bone substitute filling was performed. Because of the previously performed SAE, profuse bleeding from the cyst was not observed. The bony septations of the cavity was thoroughly curetted and thermocauterization of the whole cavity was carried out in order to decrease the bleeding from the cavity wall as an adjunctive therapy. The cavity then was filled with two fresh frozen allografts in order to mechanically enhance bone consolidation and $60 \mathrm{~mL}$ of bone substitutes (tricalcium sulfate) were also used. One piece of the fibular grafts was placed vertically in the medial corner of the cavity and the other graft was placed obliquely towards the lateral edge. The bone substitute graft was filled between the fibular allografts. Three units of erythrocyte suspension were transfused in order to maintain her
$\mathrm{Hb}$ levels and blood pressure after the operation. The bony window was implanted back in order to obtain the integrity of the bone and facilitated the bone healing. The patient had no perioperative or postoperative complications and she was completely free of pain on the third day after the operation and began to walk without any limitations. She was closely followed up since there was a possibility of a recurrence at the operation site. X-rays showed the complete removal of the tumoral mass and septations and that the two fresh frozen fibular allografts fit well in the early clinical visit in the sixth week (Figure 4a). Twenty-four months after the operation, she is still asymptomatic and pain free without any recurrence clinically and radiologically stable, showing proper consolidation of the bone grafts in the anteroposterior X-ray (Figure $4 b$ ).
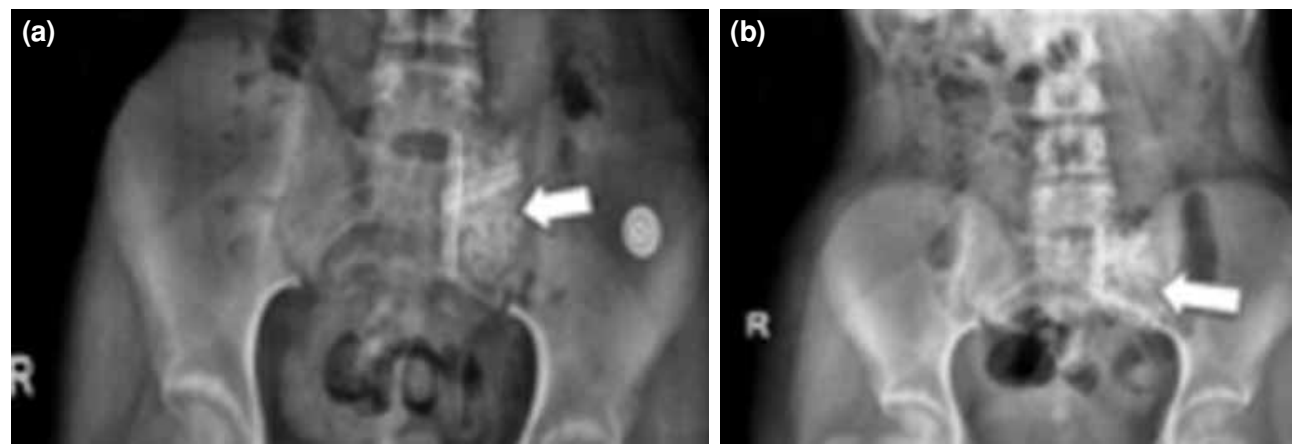

Figure 4. (a) Early postoperative anteroposterior X-ray at six week follow-up showing the positions of the fresh frozen allografts and bone substitutes in the cavity after curettage (b) anteroposterior $\mathrm{X}$-rays at the $24^{\text {th }}$ month visit revealing no recurrence and good consolidation and bony union of the fresh frozen fibular allograft. 


\section{DISCUSSION}

Aneurysmal bone cysts of the pelvis and sacrum pose challenging therapeutic problems and sacral lesions are often associated with radicular symptoms. Young patients with radicular symptoms should be carefully investigated because primary bone tumors may simulate lumbar disc pathologies. Even though open aggressive surgical curettage and bone grafting is still the recommended treatment modality in the extremities, because of the significant potential risks of hemorrhage and nerve damages, we should avoid potentially damaging curettage procedures in the sacral region. ${ }^{[4]}$

Preoperative SAE will be very helpful in preventing these morbid complications. ${ }^{[2]}$ A recent report implies that, multiple courses of embolization may be required in sacral $\mathrm{ABCs}$ because of the ongoing progression of the lesion after embolization within 4-6 weeks. $^{[4]}$ In this case, because of the severe pain and bedridden status of the patient, we preferred open surgical curettage of the lesion after SAE that provided a partial response. Also as the lesion was very near the S1-2 nerve roots and the patient had severe radicular symptoms we did not perform SAE as a unique therapeutic intervention because of the necessity of the multiple courses of embolization requiring a long time interval. After surgical resection, the patient had acute pain relief and returned to normal daily life. Following aggressive curettage and electrocauterization of the cavity, a fresh frozen allograft was inserted into the cavity in two divided parts crossing each other, one in the medial corner near the sacroiliac joint and the other in an oblique position, pointing to the superolateral corner. Fresh frozen allograft was preferred since the patient refused the use of her own fibula or iliac bone as autographs and of higher expected bony union and integration rates into the cavity defect than spongiosa chips allografts alone. During the $24^{\text {th }}$ month followup visit, the patient was not experiencing any pain or neurological compromise. X-rays showed no evidence of recurrence and the fresh frozen allografts have been integrated into the cavity and there was only a slight bony union. After intralesional curettage, the risk of recurrence is estimated to be approximately between $10-20 \%$ but large, extensive lesions necessitate en bloc resections like hemi or total sacrectomy with sacroiliac fixation which may lead to neurologic compromises like bowel and bladder dysfunction. ${ }^{[3,5]}$ In this case, intralesional curettage with bone grafting provided an excellent clinical outcome avoiding a more aggressive surgery.
Recently, authors have recommended avoiding aggressive curettage and instead, performing minimally invasive or noninvasive procedures, such as SAE, sclerosing injections and injections of boneinducing materials..$^{[2,6]}$ The aforementioned patient was admitted to the clinic and had an extensive vascularized cyst in S1-2 localization compressing the S2 root and was in such pain which necessitated narcotic analgesics. As it was an emergency condition and the mentioned treatment modalities were time consuming, we performed immediate open surgical curettage and S2 nerve root dissection to decompress the mass effect lesion and the patient had acute pain relief and full function after three days of the surgical intervention. Zoledronic acid treatment in the treatment of a sacral aneurysmal cyst has been reported by Simm et al. ${ }^{[7]}$ which was resistant to serial arterial embolizations. They imply that there is still a lack of long-term safety data for use in a child.

We conclude that treatment of sacral aneurysmal bone cysts is a challenging problem, especially in the childhood population because of the risk of profuse bleeding and neurologic deficits after open curettage or sacral resections. Arterial embolization, use of bone induction agents, bone morrow injections and bisphosphonates are contemporary treatment therapeutic options for $\mathrm{ABCs}$ in this localization. Curettage and bone grafting is still the most logical and accurate method for positive and early clinical outcomes and fresh frozen allografts may safely be used in order to fill the resultant cavity in order to provide structural and biological reinforcement.

\section{Declaration of conflicting interests}

The authors declared no conflicts of interest with respect to the authorship and/or publication of this article.

\section{Funding}

The authors received no financial support for the research and/or authorship of this article.

\section{REFERENCES}

1. Arıkan M, Togral G, Hastürk AE, Aktaş E, Güngör S. Management and retrospective analysis of primary and metastatic sacral tumors and infections: evaluation with 73 cases. Eklem Hastalik Cerrahisi 2014;25:126-32.

2. Donati D, Frisoni T, Dozza B, DeGroot H, Albisinni U, Giannini S. Advance in the treatment of aneurysmal bone cyst of the sacrum. Skeletal Radiol 2011;40:1461-6.

3. Doss VT, Weaver J, Didier S, Arthur AS. Serial endovascular embolization as stand-alone treatment of a sacral aneurysmal bone cyst. J Neurosurg Spine 2014;20:234-8.

4. Rossi G, Mavrogenis AF, Papagelopoulos PJ, Rimondi E, Ruggieri P. Successful treatment of aggressive aneurysmal bone cyst of the pelvis with serial embolization. Orthopedics 2012;35:963-8. 
5. Tsai JC, Dalinka MK, Fallon MD, Zlatkin MB, Kressel HY. Fluid-fluid level: a nonspecific finding in tumors of bone and soft tissue. Radiology 1990;175:779-82.

6. Lin PP, Brown C, Raymond AK, Deavers MT, Yasko AW. Aneurysmal bone cysts recur at juxtaphyseal locations in skeletally immature patients. Clin Orthop Relat Res 2008;466:722-8.

7. Simm PJ, O'Sullivan M, Zacharin MR. Successful treatment of a sacral aneurysmal bone cyst with zoledronic acid. J Pediatr Orthop 2013;33:61-4. 